\title{
Competitive Price and Trust as Determinants of Purchase Intention in Social Commerce
}

\author{
Cláudia Rodrigues Maia ${ }^{1,2}$ \\ Guilherme Lerch Lunardi ${ }^{1}$ \\ Décio Dolci ${ }^{2}$ \\ Lívia Castro D'Avila ${ }^{2}$ \\ ${ }^{1}$ Universidade Federal do Rio Grande do Sul, Porto Alegre, RS, Brazil \\ ${ }^{2}$ Universidade Federal do Rio Grande, Rio Grande, RS, Brazil
}

Received $1^{\text {st }}$ June 2019. This paper was with the authors for two revisions. Accepted 10 February 2020. First published online $2^{\text {nd }}$ March 2020.

Cesar Alexandre de Souza was the associate editor for this article.

Editorial assistant: Luciane Kato Kiwara

Editor-in-chief: Carlo Gabriel Porto Bellini 


\begin{abstract}
The evolution of Web 2.0 technologies and social media has changed the way online business is conducted. With increasingly popular social networks, the connections among Internet users emerge as an important source of information, allowing consumers to share their ideas, opinions, or even content on the web, in order to find better and cheaper products, originating a new type of electronic commerce, known as social commerce (s-commerce). In this context, price and trust stand out as two important factors influencing the decision to buy online. Thus, we aimed to analyze the effects of trust and competitive price on the purchase intention of Brazilian consumers in s-commerce. Through a survey conducted with 160 online consumers, we identified trust as the main predictor of consumer purchase intention in s-commerce followed by competitive prices. We also indicated a set of important antecedents of trust in the context of s-commerce. The study contributes to the literature surrounding the effects of competitive price and trust and its antecedents - as important factors that influence the intention to buy in s-commerce, providing managers with some key elements they can use to improve their firm's competitiveness in this new business environment.
\end{abstract}

Keywords: social commerce; price; trust; social media; purchasing intention. 


\section{Introduction}

The evolution of Web 2.0 technologies and social media has changed not only the way people communicate, collaborate, and live, but also how online businesses are being driven. With increasingly popular social networking sites (SNS), the various connections among Internet users emerge as an important source of information, allowing consumers to share their ideas, opinions, or even content on the web without the need for having a high knowledge of technology. This expansion of the use of SNS's has given rise to a new type of electronic commerce, called social commerce or s-commerce, which has modified the way in which online purchases have been made (Lin, Li, \& Wang, 2017). Broadly speaking, s-commerce provides a more social and interactive environment to allow customers to share their information (Busalim \& Hussin, 2016). Social commerce sites provide social interactions, such as information sharing, networking, and collaborating, to facilitate communication among consumers ( $\mathrm{Li} \& \mathrm{Ku}, 2018)$.

The popularity of SNS's such as YouTube, Facebook, Instagram, and Twitter has fundamentally influenced the behavior of consumers, who can now make informed purchases, and obtain better products, services, and prices through the exchange of reliable information with other consumers, characterizing as a unique aspect of s-commerce (S. Kim \& Park, 2013). The main purpose of visiting an e-commerce site is to find products users wish to buy, and selecting which vendor to buy from, based mainly on price, reputation, product availability, and service (Manvi \& Venkataram, 2005). According to a survey conducted in 2017 by We Are Social, more than half of the global population already uses the Internet, totaling more than 3.75 billion people online. According to the same survey, social networks users sum up 2.18 billion people, which represent $37 \%$ of the world's population, growing by more than $20 \%$ in the last year alone (Kemp, 2017).

From the perspective of organizations, s-commerce has great potential to generate value from social interactions carried out online with consumers, proving to be an important sales channel. S-commerce is growing rapidly in terms of the number of s-commerce platforms to engage with customers and support the co-creation of their brand value co-creation (Wang, Tajvidi, Lin, \& Hajli, 2019). More and more followers around the world have taken advantage of s-commerce tools (e.g., forums, chat rooms, communities, and SNS's) to operationalize their transactions in the virtual universe (B. Lu, Fan, \& Zhou, 2016; S. Kim \& Park, 2013). A survey conducted by Burson-Marsteller (Campaign Brief, 2012) pointed out that $87 \%$ of the largest companies worldwide are present in at least one social network. In China, more than half of online consumers buy their products via social media platforms (PricewaterhouseCoopers, 2013), while in Brazil about $60 \%$ of e-commerce sites use social media for sales and marketing (Emarketer, 2016). In academia, s-commerce has become a significant research area, especially in Information Systems (IS) discipline, where academicians have paid attention to this new research topic with a focus on adoption and use of social commerce (Lin et al., 2017). In this context, s-commerce emerges as a phenomenon of global interest for managers and researchers.

On the other hand, such rapid expansion has allowed the entry of small businesses, startups, and entrepreneurs which tend to have limited resources because of the low entry barrier in this market, causing in some cases negative effects such as low services to consumers, frauds, late

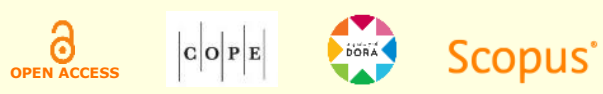


refunds, and inaccurate or imprecise information (S. Kim \& Park, 2013). Consequently, a large number of consumers have become victims of these firms, generating distrust as to the suitability of these companies and even to the advance of s-commerce. Some previous studies have suggested that mistrust is one of the main reasons why consumers hesitate or avoid doing online purchases (Gefen, 2000; Gefen, Karahanna, \& Straub, 2003; S. Kim \& Park, 2013). However, one of the main advantages of online firms is the possibility of offering products and services at low prices (B. Lu et al., 2016), a fact considered as an important characteristic of s-commerce from the perspective of consumers (Hsiao, Chuan-Chuan, Wang, Lu, \& Yu, 2010; Maia, Lunardi, Longaray, \& Munhoz, 2018).

H.-W. Kim, Xu, and Gupta (2012) examined the relationship between price and trust in the online purchase decision and found that, by evaluating these two constructs separately, trust is more likely to influence purchase intention than price. Although some previous studies considering different forms of e-commerce have also highlighted the importance of price and trust in online shopping (Gefen, 2000; Gefen et al., 2003), the synergy effect of these two factors on online purchase decision needs more attention by managers and researchers, especially in this new online paradigm and growing phenomenon called s-commerce.

For companies operating in the online market, this topic is a strategic issue, as they must decide whether to compete with their competitors based on price or trust. Assuming that price has long been considered a key predictor in customer choice and that consumers can easily compare prices among vendors over the Internet and select cheaper alternatives, vendors could consider developing competitive pricing strategies. On the other hand, such vendors might consider developing trust-based strategies, whether by investing in building a good reputation, improving service quality, or cultivating customer satisfaction, for example. More specifically in s-commerce, S. Kim and Park (2013) highlight that building trust is more important for this kind of business because s-commerce is built on social networking sites, where consumers not only purchase products and services but also share their shopping experiences and product information.

Therefore, considering these two aspects, s-commerce firms could try to strike a balance between price and trust, pondering different weights on the two factors in their strategies. Therefore, we aim in this study to examine the relationship between prices, trust, and purchase intention in the context of s-commerce by proposing a model that explains and predicts how price advantages and trust affect Brazilian consumers' intentions in s-commerce shopping. We also identify the main antecedents of trust in order to provide new insights about those factors that influence the formation of trust in s-commerce.

This study did not focus on the specific characteristics and components present in s-commerce but in the context of s-commerce, which presupposes the presence of reviews, recommendations, and peer interaction in the websites. Therefore, in this research, we studied the consumers' perception that makes use of s-commerce tools to support their purchase decision. S-commerce, thus, is the main object of this research in which we analyzed some variables commonly used in the e-commerce studies that in the s-commerce context can influence directly or indirectly the perception of consumers about price, trust, and intention to buy on the website.

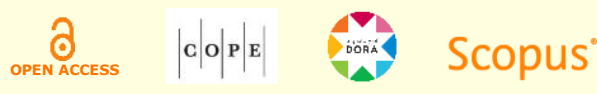


In this sense, the study contributes to the literature examining the effects of price and trust as important factors that influence online intention to buy in s-commerce. The research also offers practical insights for managers and Internet vendors with some key elements they can use to improve their firm's competitiveness in s-commerce.

The remainder of the paper is organized as follows. In second section, we review the literature on s-commerce, trust, and price (here called competitive price) as antecedents of purchasing intention. We still present some trust-correlated studies, the hypotheses, and the research model of the study. We then present the methodology and, in fourth section, we test the relationships in the model, presenting the data analysis and the main research findings. Finally, in fifth section, we conclude with a discussion of our findings and include implications for theory and practice, limitations, and directions for future research.

\section{Social commerce background}

Although there is no standard definition, s-commerce is defined as a subset of e-commerce that involves the use of social media to assist in business transactions and online transactions (Liang \& Turban, 2011; Zhang \& Benyoucef, 2016). Its main peculiarity is the interaction and social participation - characterized as a place where people can collaborate, obtain advice from other consumers, as well as find and compare goods and services more easily, related to characteristics, prices, and suppliers. S-commerce has three main attributes: (a) it must have social media technologies, (b) it must allow interactions between the community, and (c) it must enable execution of commercial activities (Liang \& Turban, 2011; Lin et al., 2017). The presence of SNS has become a success among its users because it enhances customer participation, allows them to collect socially rich information and exchanging knowledge, resulting in a more reliable and sociable online transaction environment (B. Lu et al., 2016).

Through s-commerce, retailers can engage consumers and gather information about new products and services, as well as recommendations and sharing on social media that also affect the purchase habits of consumers. Likewise, consumers have the possibility to compare opinions (S. Kim \& Park, 2013), prices, and recommendations, which can influence the decision for the realization or not of a deal. In such situations, different tools and websites for comparison of prices on the Internet have helped consumers to obtain reference prices, allowing them to judge whether the price of the product is high or low (Sullivan \& Kim, 2018). Intuitively, transaction utility represents the price advantage or disadvantage of a deal relative to a reference price.

The first studies carried out on this subject focused specifically on the monetary aspects of price, without considering nonmonetary attributes such as the amount of time and emotional efforts spent by consumers in all stages of the purchase process. This certainly influences the decision on whether or not to purchase a particular product and from whom to buy. In the digital market, risk is also characterized as an important (nonmonetary) aspect, after all, a disappointing purchase (either by a false or malicious website, or by a delivered product being different from the advertised, or even a delay or non-delivery of the product) can affect consumer trust (Grewal, Iyer,

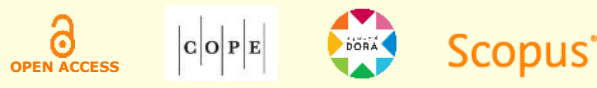


Krishnan, \& Sharman, 2003). Thus, price and trust should be considered as two important factors that influence the purchasing decision of consumers in s-commerce.

\section{Trust and competitive price as antecedents of purchase intention}

Several studies (Gefen et al., 2003; Hajli, 2014; Maia et al., 2018; S. Kim \& Park, 2013) have argued that in an online store, trust has become a key predictor of customer decisions in online shopping. According to Doney and Cannon (1997), buyer's trust in a seller is a precursor to her/his buying decision and a key factor influencing her/his intention to buy. In fact, trust has often been considered as one of the most important prerequisites for the success of e-commerce (Pavlou, Liang, \& Xue, 2007), as well as mobile commerce (Luo, Li, Zhang, \& Shim, 2010) and s-commerce (Hajli, 2014; S. Kim \& Park, 2013). According to Morgan and Hunt (1994), trust implies faith in a firm and product and is present when a party trusts the partner's integrity and dignity. To S. Kim and Park (2013), s-commerce focuses not only on the sale of products and services but also on building trust among its users in order to induce buying and recommendation intentions, thus generating more sales. In fact, consumer social interactions can act as a tool to increase consumers' trust in online businesses, thereby influencing their buying decision. In this respect, the following hypothesis is proposed:

H1: Trust has a positive effect on consumers' purchase intention in s-commerce.

Although trust appears to be one of the main factors affecting the success of e-commerce, previous research has also highlighted the importance of price in the purchasing process (Zeithaml, 1988). According to Lee and Lee (2011), when goods or services are offered at a high discount rate or a lower price, the consumer tends to buy more. In the case of online stores, the ability to easily compare prices from different vendors gives consumers the advantage of getting cheaper products than in traditional stores (Oh, Yoon, \& Lee, 2006). This situation seems to be more intense in scommerce, where information, suggestions, and recommendations on vendors circulate more easily through social media, including both monetary and nonmonetary elements. Grewal, Monroe and Krishnan (1998) define price as the value that the consumer is willing to spend to purchase a product or service, including monetary and nonmonetary items. Thus, a product whose price is seen as cheap or reasonable by the final consumer is more likely to be acquired.

However, consumer perceptions of high versus low prices are subjective and based on the perceived value they receive from the product in relation to the price they paid for the product. Frequently, offering the lowest price alone does not guarantee that consumers will come and buy at a specific site (Ba, Stallaert, \& Zhang, 2007), since the price has long been considered as a quality signal of a product too (Lichtenstein, Ridgway, \& Netemeyer, 1993; Zeithaml, 1988). In this sense, attractive price - here called competitive price - represents one's subjective perception of the price at a particular Internet vendor as a price lower than that offered by the other vendors or a price made more attractive due to additional incentives, such as longer payment terms, lower risk, time, or efforts. Based on the above arguments, we propose the following hypothesis:

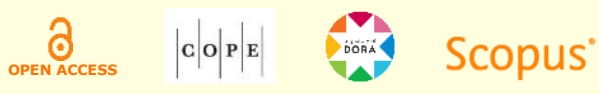


H2: Competitive price has a positive effect on consumers' purchase intention in s-commerce.

\section{Trust and related studies}

Although trust is one of the factors that has received the most attention in the e-commerce literature, many online companies have had difficulty gaining the trust of their customers (S. Kim \& Park, 2013). The main explanation for this is that the online business environment is unpredictable and there are no face-to-face interactions between customers and vendors (Doney \& Cannon, 1997; Gefen, 2000). These uncertainties stimulate consumers to evaluate both products and firms more carefully, which justifies the increase of online searches through social networks, rivaling the traditional search for consumer preference in both research and evaluation of products and services (Hajli, 2015).

Chang and Chen (2008) argue that on any kind of e-commerce, trust can facilitate interactions between sellers and buyers, providing opportunities for online businesses to achieve their goals. Given the important role that trust plays in e-commerce, previous studies (e.g., Flavián, Guinalíu, $\&$ Gurrea, 2006) have suggested a number of characteristics related to the customer, website, and organization that play critical roles in building trust online. First, the variables associated with customer characteristics include the propensity for trust and experience on the Internet (Gefen, 2000). Secondly, the characteristics of web pages include information quality, service quality, perception of website usefulness, its design, social existence, and safety of personal information (Koufaris \& Hampton-Sosa, 2004). Finally, the organization's characteristics include firm reputation, scale, offline existence, and experience/familiarity with an online business (Jarvenpaa, Tractinski, \& Vitale, 2000).

S-commerce has unique features that can influence consumer trust. Thus, identifying which features can increase or even build trust in s-commerce firms can help organizations define and prioritize strategies and actions to that end, although a number of studies have already examined trust in online business configurations. Firm reputation, for example, may indicate the level of consumer trust with this firm, suggesting that the reputation of an s-commerce firm will have a positive effect in shaping the relationship between it and its customers, becoming a determinant factor of trust (Jarvenpaa et al., 2000). According to Doney and Cannon (1997), firm reputation is defined as the extent to which consumers believe the firm is honest and concerned about its customers. Some previous studies involving e-commerce companies have demonstrated a close relationship between reputation and trust (Maia et al., 2018; S. Kim \& Park, 2013). In scommerce, according to S. Kim and Park (2013), users tend to consider firm reputation as an important factor in assessing trust in the firm and in buying products or services. Furthermore, Grund and Gürtler (2008) claim that the recommendation system, for example, works as an important instrument to build a seller's reputation, aiming to reduce the consumers' perception of uncertainty about the products and the firm. Thus, we propose the following hypothesis:

H3: The reputation of a firm has a positive effect on consumers' trust in s-commerce.

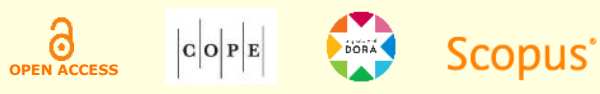


In addition to a firm reputation, it can be seen that other aspects also have a significant influence on trust formation (D. J. Kim, Ferrin, \& Rao, 2008). S. Kim and Park (2013) suggest that information quality is another determinant of consumer trust in s-commerce. The quality of a website, for example, may be associated with the relevance, accuracy, comprehension, and usefulness of the information provided by it. Once online shoppers have limited sources of information about the products and services they want to purchase, they depend heavily on the information provided by websites and e-retailers as their purchasing decisions are based primarily on this information (D. J. Kim et al., 2008). Liao, Palvia and Lin (2006) suggest that high-quality information about products and services has a positive effect on the trust of e-retailers and companies, particularly e-commerce companies. In this sense, consumers will tend to rely on sites that provide accurate and timely information.

In the case of companies that participate in s-commerce, the quality of information may be even more important than for other e-commerce companies because the information related to the product or service is also provided by other consumers who bought products on this website, using resources such as evaluations and participation in forums or communities. In this regard, we propose the following hypothesis:

H4: Information quality has a positive effect on consumers' trust in s-commerce.

The literature has also suggested transaction safety as another antecedent of trust with online companies, which is defined as the extent to which s-commerce users believe that the website by which they wish to transact provides a high level of security in terms of the transaction and transaction-related information (Cheung \& Lee, 2006; S. Kim \& Park, 2013). As there is no faceto-face transaction in the online environment, transaction safety can be a key determinant of trust, being associated with the presence of safety controls and the ability of the website in verifying the online shoppers' identity for security purposes. Koufaris and Hampton-Sosa (2004) argue that e-commerce users are generally anxious about the level of security involved in the entire buying process. Likewise, Hoffman, Novak, and Peralta (1999) point out that transaction safety is an important factor limiting online shopping, with privacy control and security factors influencing consumer trust.

Thus, a high level of transaction safety reduces consumer anxiety about transactions and therefore will exert a positive effect on their behavioral trust, particularly in the online business context (Koufaris \& Hampton-Sosa, 2004). Maia, Lunardi, Longaray and Munhoz (2018) suggest that the use of online comments and ratings, as well as the participation in forums and communities, depending on how they are, positive or negative, may increase or decrease the consumer perception of the safety of transactions made electronically and the delivery conditions of the product. In this perspective, consumers who consider a high level of transaction safety as relevant to their level of trust may consider s-commerce as a potential online marketplace. Therefore, the following hypothesis is proposed:

H5: Transaction safety has a positive effect on consumers' trust in s-commerce.

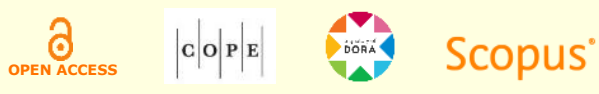


Finally, consumer expectations about the delivery of products purchased online are another aspect that can affect consumer trust with the seller. Most previous studies discuss the importance of product delivery to traditional brick and mortar firms, while a few emphasize their needs in the e-commerce context (Ramanathan, 2010; Yu, Subramanian, Ning, \& Edwards, 2015). According to Eurobarometer (European Commission, 2013), the problems experienced with online businesses in Europe are mostly related to delivery rather than the product itself. The most cited problems experienced by e-consumers are delivery at home when nobody is there, delay in the delivery, high delivery costs, lack of a way of tracking delivery status, and the need to collect the product from a distant collection point, demonstrating that shipment or delivery becomes an essential part of e-commerce. In Brazil, the most common problems related to e-commerce are associated with product delivery too, highlighting the delivery when nobody is at home, people living where the mail does not deliver, and charges for high shipping costs (Cristofolini, 2017).

One of the biggest challenges of e-commerce, today, is the logistics of supply and distribution of the products sold online. When talking about delivery capacity, it is important to emphasize that this does not only refer to the cost of transportation and delivery time, but also to the delivered product. Contrary to purchases in physical stores, consumers do not immediately own the purchased product after purchase online; that is, they have to wait a certain amount of time in order to receive the product (Huseynov \& Yildirim, 2016). Recently, the assessments of customer service quality and logistics service quality have been included in the consumer feedback system (Yu et al., 2015). Thus, showing that a product has a good process delivery can increase consumers' trust with regard to the firm that is selling a product or service over the Internet. In this regard, we propose the following hypothesis:

H6: Product delivery has a positive effect on consumers' trust in s-commerce.

Following, Figure 1 shows the research model, containing six different hypotheses. We consider that the intention to buy an online product or service in s-commerce firms is influenced by both trust and competitive price, and trust can be influenced by the reputation of the firm, the quality of the information on the website, the safety of the transaction, and the product delivery process. 


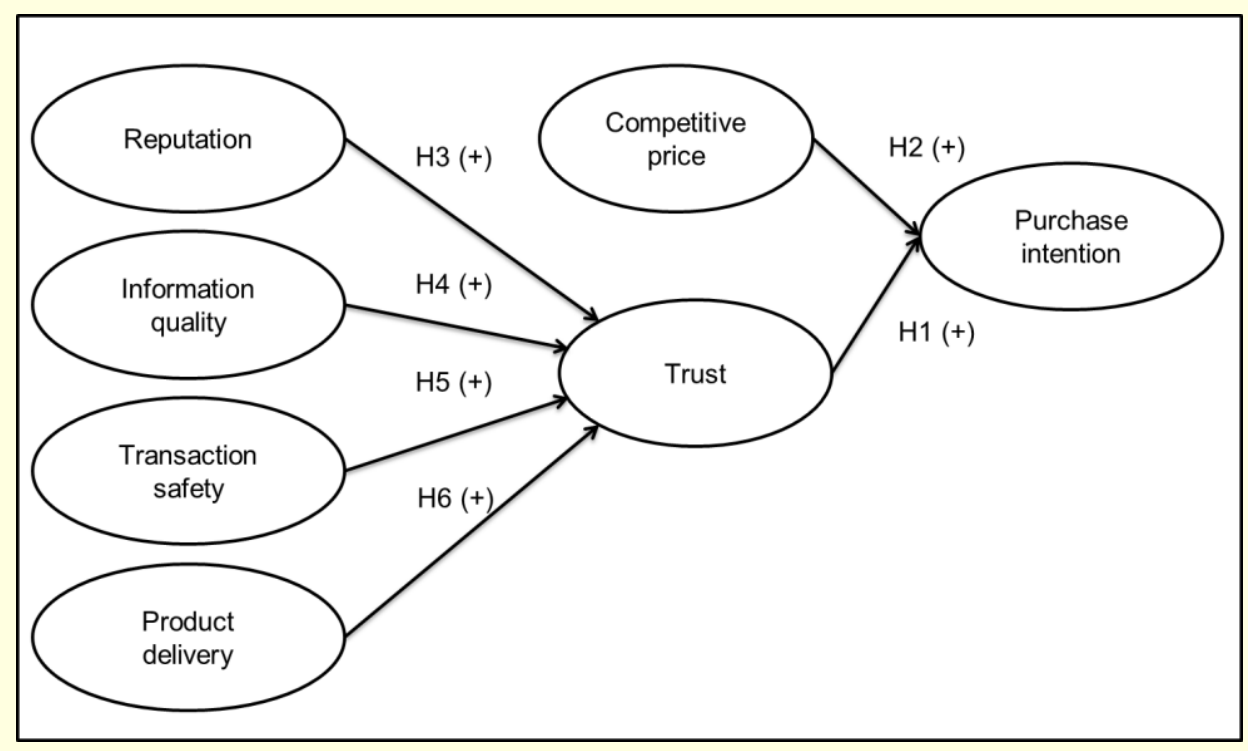

Figure 1. Research model

This theoretical framework is consistent with previous studies carried out in different e-commerce contexts, mainly the one made by S. Kim and Park (2013). However, the present study perceived the opportunity to make a new articulation (and measurement) of the price issue. Results from S. Kim and Park (2013) provide no support for the hypothesis that price - named economic feasibility by the authors - has a positive effect on consumers' trust in s-commerce. According to the authors, "this suggests that although discounts play an important role in s-commerce, not all users emphasize discounts when determining their trust in s-commerce firms" (S. Kim \& Park, 2013, p. 329). Thus, differently from this previous study, we investigate the relationship between competitive price and purchase intention, not its influence on consumers' trust.

\section{Method}

This study is characterized as a descriptive research, operationalized through a survey applied to 165 participants of the social network Facebook. From this total, we excluded five respondents for presenting too many questions in blank or using only one point in the scale Likert in all answers, totalizing a sample of 160 consumers. Inclusion criteria were defined that participants should be over 18 years old and have searched or purchased a product on the Internet in the last three months, making use of recommendations, evaluations, forums, or online reviews about the product they wanted to buy. The sample is classified as non-probabilistic and the respondents were selected by convenience. We sent messages through Facebook inviting different users to participate in a survey on e-commerce and social media, asking them to access the questionnaire through a link and, if possible, to share the invitation with their friendship network. Each respondent was asked to select one of his/her latest Internet shopping experiences to answer the proposed instrument.

In order to describe the study sample, we highlighted the following aspects: in terms of gender, $82(51.3 \%)$ participants are women and $78(48.7 \%)$ are men, the mean age is 35 years ( \pm 11 years),

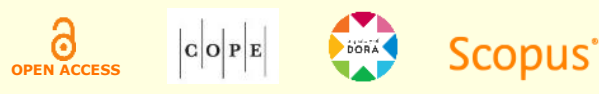


the predominant family income ranges from eight to twenty Brazilian minimum wages $(37.5 \%)$ and more than twenty minimum wages (38.1\%); with regard to schooling, $25.6 \%$ have completed university education and $45.6 \%$ have post-graduate education; with regard to the frequency of purchase on the Internet, $32.5 \%$ make about one purchase per month and $34.5 \%$ buy at least once a week. Electronics (21.9\%), fashion articles and accessories (20.6\%), informatics $(11.3 \%)$, and household appliances $(10.0 \%)$ were the main chosen products to be evaluated by the respondents - on the other hand, travel and tourism products $(5.6 \%)$, domestic utility $(6.3 \%)$, and health and beauty $(6.9 \%)$ were the least chosen products.

We verified the sample size adequacy using $G^{*}$ Power 3.1.9.4 software. For this, we observed two parameters as suggested by Cohen (1988) and Hair, Sarstedt, Hopkins and Kuppelwieser (2014): (a) the recommended power of 0.80 and $(b)$ the size of the effect $\left(f^{2}=0.15\right)$. The calculated minimum sample was estimated in 85 cases, indicating the sample size in this study is adequate.

\section{Development of the instrument}

We developed the research questionnaire based on constructs identified in the literature to represent the conceptual model of the research. With the exception of the aspects regarding the variable product delivery, proposed by Maia et al. (2018), all other constructs had already been previously identified and validated by S. Kim and Park (2013). To measure competitive price, we adapted the items regarding economic feasibility suggested by S. Kim and Park (2013), changing the sentence of two questions, maintaining one of them unchanged and eliminating another one.

First, the questionnaire was translated from English to Portuguese and then it was re-translated to English (back translation process). Subsequently, we submitted the questionnaire to three specialists from the Management field to evaluate it. For the operationalization of the items, a five-point Likert scale was used, ranging from totally disagree (1) to totally agree (5). The same scale was used to evaluate consumer purchase intentions in s-commerce. We added to the instrument questions related to demographics (including gender, age, schooling, family income, and the frequency with which one usually buys products online). Appendix presents the questionnaire and descriptive statistics.

With the data collection instrument previously determined, we carried out a pretest with two specialists in the IS field followed by a group of Business Administration graduate students with academic experience in e-commerce, in order to identify possible problems of formatting and/or comprehension of the questions included in the questionnaire. Some modifications were made to the respondents' better understanding of the issues. After these minor adjustments, we sent messages inviting different Facebook members to access the online questionnaire.

\section{Instrument validation}

We validated the instrument after the data collection procedures. Initially, we performed the exploratory factor analysis (EFA) for each proposed construct individually, freeing the number of

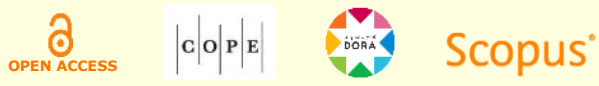


extracted factors as suggested by Koufteros (1999), which is called EFA within the block. Using the within-block factor analysis methodology for the seven constructs of the model, we found a single factor in each block with relatively high loadings ranging from Reputation (0.73 to 0.88), Information quality (0.79 to 0.82$)$, Transaction safety $(0.77$ to 0.82$)$, Product delivery ( 0.73 to 0.89 ), Competitive price ( 0.63 to 0.88 ), Trust ( 0.79 to 0.88 ), and Purchase intention ( 0.88 to 0.95). Thus, this initial analysis confirmed the unidimensionality of the constructs, since the factor loadings converged to a single factor. Afterward, we ran the confirmatory factor analysis (CFA) through the structural equation modeling technique, using the software SmartPLS 3.0 (Partial Least Squares), in order to verify the measurement model used in the study.

According to Hair, Risher, Sarstedt, and Ringle (2019), PLS-SEM is now widely applied in many social science disciplines, including Organizational Management, Information Systems, and Marketing. PLS-SEM is appropriate for predictive applications and theory building, especially suited for data that does not necessarily exhibit a normal distribution as required by covariancebased SEM (Chin, 1998). This method has been very appealing to many researchers because it enables to estimate complex models containing many constructs, items, and structural paths without imposing distributional assumptions on the data (Hair, Hult, Ringle, \& Sarstedt, 2017).

The validity and reliability of the items and constructs were assessed by examining the loadings of items on their respective latent constructs. As shown in Table 1, all items loaded heavily and significantly (at $\mathrm{p}<.05$ ) on their respective constructs (indicating individual item reliability). We assessed the reliability of scales through composite reliability (CR) and Cronbach's alpha. All CR scores exceeded the minimum threshold level of 0.70 , while Cronbach's alpha exceeded 0.60 , indicating good reliability (Table 2). To validate the model as a whole, we used the goodness of fit $(\mathrm{GoF})$ index that is a single measure to validate the performance of combined measurement and structural models. The GoF value was 0.633 , indicating very good adequacy of the model in explaining the empirical data as suggested by Wetzels, Odekerken-Schröder and Van Oppen (2009).

Convergent validity of the constructs was also evaluated using the average variance expected (AVE) criterion, whose values exceeded the minimum limit of .50 (Table 2). Factor loadings and construct AVE values serve as a basis to ensure that the constructs of the proposed model demonstrate convergent validity. We assessed discriminant validity with the cross-loadings criterion (each item is expected to be greater than all of its cross-loadings) and AVE (the square root of the AVE is greater than the correlations among constructs in the model, highlighted in bold on the diagonal), indicating that the constructs achieved discriminant validity (Fornell \& Larcker, 1981). 
Table 1

\section{Factor loadings}

\begin{tabular}{|c|c|c|c|c|c|c|c|}
\hline Item & $\begin{array}{l}\text { Purchase } \\
\text { intention }\end{array}$ & $\begin{array}{l}\text { Information } \\
\text { quality }\end{array}$ & $\begin{array}{l}\text { Product } \\
\text { delivery }\end{array}$ & Reputation & $\begin{array}{c}\text { Transaction } \\
\text { safety }\end{array}$ & Trust & $\begin{array}{c}\text { Competitive } \\
\text { price }\end{array}$ \\
\hline BUY1 & .919 & .583 & .390 & .450 & .460 & .618 & .431 \\
\hline BUY2 & .868 & .484 & .370 & .448 & .449 & .524 & .417 \\
\hline BUY3 & .945 & .609 & .364 & .467 & .486 & .642 & .427 \\
\hline INFO1 & .322 & .758 & .319 & .326 & .401 & .484 & .419 \\
\hline INFO2 & .478 & .833 & .466 & .406 & .570 & .612 & .607 \\
\hline INFO3 & .658 & .823 & .390 & .340 & .529 & .608 & .441 \\
\hline DEL1 & .351 & .411 & .875 & .351 & .361 & .509 & .375 \\
\hline DEL2 & .252 & .326 & .651 & .105 & .281 & .262 & .370 \\
\hline DEL3 & .387 & .461 & .907 & .310 & .402 & .542 & .384 \\
\hline REPUT1 & .316 & .262 & .141 & .795 & .413 & .439 & .278 \\
\hline REPUT2 & .447 & .482 & .387 & .808 & .508 & .662 & .379 \\
\hline REPUT4 & .434 & .302 & .250 & .847 & .398 & .547 & .290 \\
\hline SAFE1 & .333 & .446 & .357 & .432 & .802 & .437 & .417 \\
\hline SAFE3 & .373 & .463 & .338 & .385 & .720 & .373 & .356 \\
\hline SAFE4 & .494 & .580 & .345 & .482 & .868 & .606 & .410 \\
\hline TRUST1 & .448 & .559 & .430 & .616 & .493 & .784 & .469 \\
\hline TRUST3 & .661 & .654 & .428 & .603 & .578 & .889 & .424 \\
\hline TRUST4 & .536 & .583 & .572 & .536 & .467 & .858 & .341 \\
\hline PRICE1 & .455 & .562 & .410 & .460 & .488 & .536 & .807 \\
\hline PRICE2 & .292 & .430 & .319 & .144 & .301 & .274 & .797 \\
\hline PRICE3 & .253 & .338 & .249 & .197 & .260 & .184 & .648 \\
\hline
\end{tabular}

Table 2

Shared variance, correlations, and reliability of constructs

\begin{tabular}{|c|c|c|c|c|c|c|c|c|c|c|c|}
\hline & Mean & $\alpha$ & $\mathrm{CR}$ & AVE & $\begin{array}{l}\text { Purchase } \\
\text { intention }\end{array}$ & $\begin{array}{l}\text { Infor. } \\
\text { quality }\end{array}$ & $\begin{array}{l}\text { Product } \\
\text { delivery }\end{array}$ & Reput. & $\begin{array}{l}\text { Trans. } \\
\text { safety }\end{array}$ & Trust & $\begin{array}{l}\text { Comp } \\
\text { price }\end{array}$ \\
\hline Purchase int. & 4.36 & .90 & .936 & .830 & .91 & & & & & & \\
\hline Inf. quality & 4.34 & .73 & .847 & .649 & .62 & .81 & & & & & \\
\hline Prod. delivery & 4.08 & .76 & .857 & .670 & .41 & .49 & .82 & & & & \\
\hline Reputation & 4.48 & .76 & .858 & .667 & .50 & .45 & .34 & .82 & & & \\
\hline Trans. safety & 4.17 & .72 & .840 & .638 & .51 & .63 & .43 & .55 & .80 & & \\
\hline Trust & 4.35 & .80 & .882 & .714 & .66 & .71 & .56 & .69 & .61 & .85 & \\
\hline Comp. price & 4.23 & .64 & .797 & .569 & .47 & .61 & .45 & .39 & .49 & .48 & .75 \\
\hline
\end{tabular}

We took some steps to assess method bias commonly associated with self-reported measures captured via a common instrument following Podsakoff, MacKenzie, Lee, and Podsakoff (2003) 
procedural and statistical remedies. First, we tried to protect respondent anonymity and we separated the measurement of the predictor and criterion variables in different blocks. Using these procedural remedies can minimize, if not totally eliminate, the potential effects of common method bias (CMB). Then, we examined the correlations among all the constructs of the model. Evidence of bias exists if any of the constructs are highly correlated with each other $(r>.90)$ (Pavlou et al., 2007). In our study, the greatest correlation between two constructs was .71, which indicates that $\mathrm{CMB}$ is not an issue. Finally, we performed Harman's one-factor test by including all items in a principal component factor analysis and examined the un-rotated factor solution to determine the number of factors that are necessary to account for the variance in the items. Evidence of $\mathrm{CMB}$ exists either if a single factor emerges or if one general factor accounts for the majority of the covariance among the items. In our study, four factors emerged, the largest of which accounted for 46.0 percent of the variance, which indicates CMB is probably not an issue.

Finally, we assessed the multicollinearity among the independent variables using the variance inflation factor (VIF) scores, which ranged between 1.307 and 1.966. The results also showed that the VIF values of individual items ranged from 1.18 to 3.99, indicating that multicollinearity is probably not a serious concern in this study (Appendix) (Hair, Sarstedt, Hopkins, \& Kuppelwieser, 2014).

\section{Results and discussion}

In order to analyze the predictive and causal relationship among the constructs, we employed the variance-based SEM (Partial Least Squares) to evaluate the structural model. In PLS, the relationships among constructs can be determined by examining their path coefficients and related $t$ statistics via the bootstrapping procedure where subsamples are randomly drawn (with replacement) from the original set of data. These subsamples are then used to estimate the model in a repeated process involving a large number of random subsamples - typically ranging from 500 to 5,000 samples - that are used to derive standard errors for the estimates (Hair et al., 2017). Therefore, the bootstrapping procedure (5,000 subsamples) was conducted to estimate the general adherence of the model, as well as its parameters. We evaluated the normality of distribution by using Kolmogorov-Smirnov and Shapiro-Wilk tests, which evidenced that data was not normally distributed, reinforcing the use of PLS-SEM as more appropriate with nonnormally distributed data (Hair, Risher, Sarstedt, \& Ringle, 2019).

Results from the structural model indicated that both trust and competitive price have positive and significant effects on consumer purchase intention in the context of s-commerce, explaining $45.8 \%$ of the variance of the dependent variable (purchase intention), thereby supporting hypotheses $\mathrm{H} 1$ and $\mathrm{H} 2$. In this sense, price and trust indicate a significant explanatory power and predictive relevance of the structural model, being trust $(\beta=.56 ; \mathrm{p}<0.000)$ the main predictor of s-commerce purchase intention.

These findings are consistent with previous studies conducted in different e-commerce contexts (H.-W. Kim, Xu, \& Gupta, 2012; S. Kim \& Park, 2013). Although competitive price also

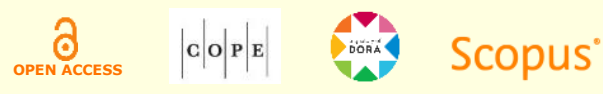


influences the purchase decision in s-commerce, trust is the most important element, suggesting that consumers who use social networks in their purchasing process are not focused solely on the purchase of the product or service. In this sense, the information obtained through SNS can compensate for the uncertainty that the online purchase generates, thus increasing the trust in the realization of the purchase. Chang and Chen (2008) further point out that a lack of trust can be a barrier for consumers to shop online until they have enough trust to recommend or buy products on a website. Therefore, the trust provides consumers with an opportunity to increase purchase intention.

Regarding competitive price $(\beta=.19 ; \mathrm{p}<.05)$, we found that this variable secondarily influences the purchase decision of s-commerce consumers, suggesting that products or services with price advantages do also attract consumer attention, increasing their purchase intention. Sullivan and Kim (2018) claim that perceived competitive price is associated with both perceived quality and perceived low price. In an online environment, consumers perceive price differently. A perceived competitive price can be considered less cost from the consumer perspective when they pay less or want to reduce other costs of the product acquisition such as delivery time, security, trust, and reputation, for example. With different tools available to compare price references across shopping websites, consumers are able to judge whether a product price is high or low (Sullivan $\&$ Kim, 2018). Thus, consumers may develop high expectations of product quality with the lowest price they are willing to pay for the product. The path coefficients of the structural model are shown in Figure 2.

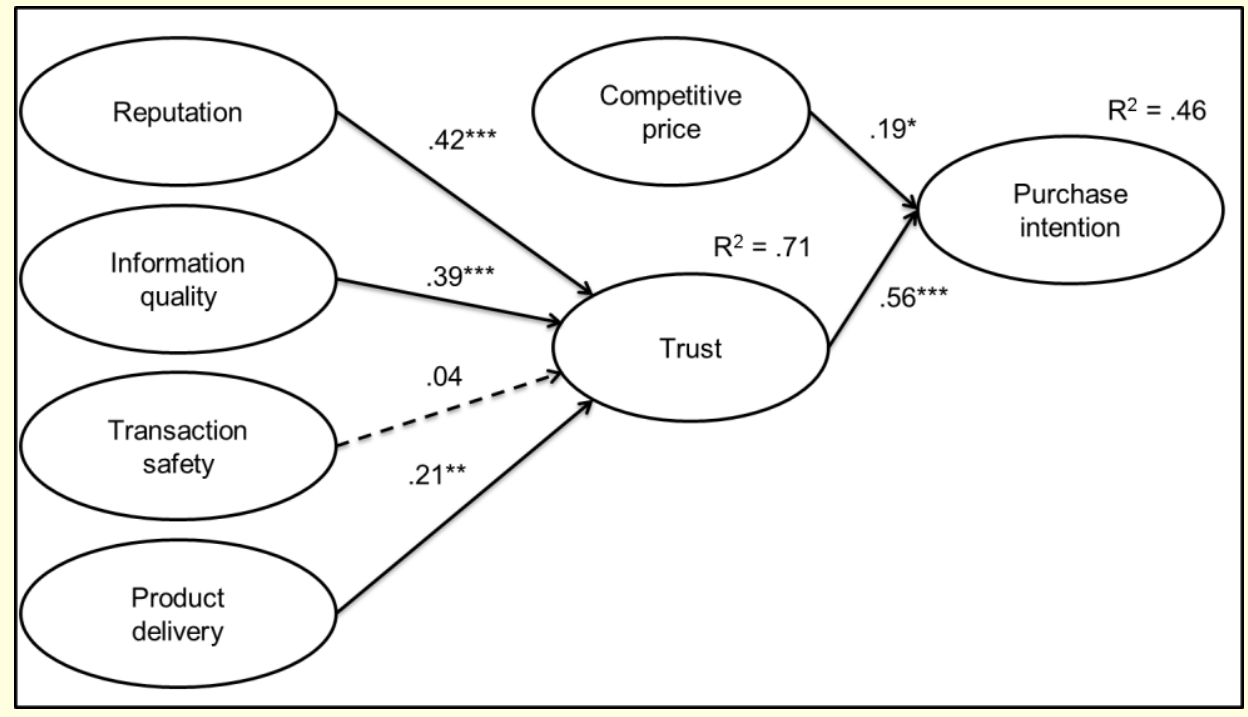

Figure 2. Structural model

Regarding the antecedents of trust, the results also presented a high level $(71.3 \%)$ of the explanation of the dependent variable, suggesting that reputation, information quality, and product delivery constitute important aspects capable of influencing the trust of consumers of scommerce websites. Among those antecedents, firm reputation was the main predictor $(\beta=.42$; $\mathrm{p}<.000$ ) of trust, confirming hypothesis H3. This suggests that s-commerce consumers emphasize firm reputation when it comes to buying a product or service to avoid the various risks associated

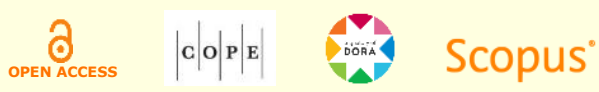


with an online transaction such as fraud, product non-delivery, problem solving, among others (S. Kim \& Park, 2013). Grund and Guertler (2008) suggest that a recommendation system is an important tool for building online vendor reputation, reducing consumer uncertainty about products and thus increasing their trust in the seller. In this way, companies should identify and encourage buyers and opinion leaders to provide positive information about their products through social networks (Tubenchlak, Faveri, Zanini, \& Goldszmidt, 2015).

The information quality $(\beta=.39, \mathrm{p}<.000)$ also influences significantly consumer trust in $\mathrm{s}$ commerce, playing an important role in the formation of consumer trust with the online seller, providing support for $\mathrm{H} 4$. The quality of a website is often associated with the relevance, accuracy, and usefulness of the information available on it. Thus, consumers tend to rely more on websites that provide accurate and timely information (Hong \& Yang, 2009). According to Delone and Mclean (2004), the quality of information is associated with the informative content of the website, which in addition to its importance for e-commerce also plays a critical role for consumers in s-commerce, especially because they depend almost exclusively on the information provided on these sites, since their sources of information about products and services are limited (D. J. Kim et al., 2008). In this sense, the quality of the information available to consumers is an important determinant of the trust of companies that work in s-commerce.

Concerning the association between online transaction safety and trust, no significant positive relationship was found (at the 5\% level), thus rejecting hypothesis $\mathrm{H} 5$. As there is no face-to-face transaction in virtual environments, website safety and payment method are elements that can reduce the anxiety level of consumers (D. J. Kim et al., 2008). However, one of the characteristics of s-commerce is the intense use of online comments and evaluations from the web, as well as the participation of consumers in forums and communities, which increases the consumer perception of the safety of the transactions that he/she makes electronically (Maia et al., 2018). According to De Valck (2005), consumers generally attach great importance to the opinions of others and often use them as the only source or predominant source of information in the prepurchase phase, which can minimize their doubts about seriousness, quality, and trust in the online seller, without focusing directly on transaction safety.

Finally, a significant positive relationship was found between product delivery $(\beta=.21, p<.01)$ and trust in s-commerce, thus confirming hypothesis H6. Nowadays, one of the biggest challenges of e-commerce - including s-commerce - is related to the logistics of supply and distribution of products sold on the Internet. According to Ramanathan (2010), late arrival or non-arrival of the product, the accuracy of the order, and damage of the product significantly increase customer dissatisfaction. In this sense, when talking about delivery capacity, it is important to emphasize that this refers not only to the delivery time but also to the delivered product (Yu et al., 2015). Companies that have attractive delivery times and can guarantee that the delivered product is the expected one and that it will arrive in good conditions end up gaining the trust of its consumers. In s-commerce, the use of online comments and assessments allows consumers to identify companies that they can or cannot relate with, considering the delivery conditions of the product as well. In the research carried out by Maia et al. (2018), the authors identified that the fact that a website is well-known or does not have disseminated complaints in the network, whether related

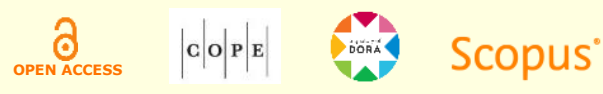


to the suitability of the firm or product delivery, is a form used by consumers to ensure that the purchase is secure, thus interfering with consumer trust with the online firm.

We still assessed the predictive quality of the model using the Stone-Geisser $\left(Q^{2}\right)$ test and the effect size $\left(f^{2}\right)$ test. A model has predictive relevance when $Q^{2}$ is above zero; specifically in this study, all endogenous latent variables presented predictive relevance values well above zero, ranging from 0.297 to 0.416 for Purchase Intention, and 0.341 to 0.550 for Trust. Following Cohen (1988), the $f^{2}$ magnitudes of $0.02,0.15$, and 0.35 represent small, medium and large degrees of effect size, respectively. So, we found that Trust $\left(f^{2}=0.44\right)$ possesses a strong effect on Purchase Intention, quite differently from Competitive Price $\left(f^{2}=0.05\right)$, which presented a small effect. Reputation $\left(f^{2}=0.42\right)$, in turn, possesses a strong effect on Trust whereas Information Quality $\left(f^{2}=0.29\right)$ and Product Delivery $\left(f^{2}=0.11\right)$ present medium and small effects on Trust, respectively.

\section{Conclusions}

In the present study, we examined some determinants of consumer purchase intention in the context of s-commerce. We surveyed 160 users of the social network Facebook that make use of s-commerce tools to support their purchase decision. Notwithstanding the effect of competitive price, the study reveals a series of other exogenous variables that also have an effect on the purchase intention, which can be managed by companies that operate in s-commerce, such as company reputation, information quality of the website, and product delivery process. In addition, we found that trust can be considered as an endogenous variable mediating the influence of these variables in the purchase intention, standing out as its main predictor, presenting an effect almost three times higher than price advantages, according to the perception of Brazilian consumers in s-commerce. Thus, we can conclude that the better the issues associated with the firm's reputation, the quality of the information available on the website, and the processes involving the way a product is delivered, the better the firm's commercial performance in this online shopping environment. Our results provide contributions to both managers and researchers. To managers, we provide relevant information that can help them define and prioritize their organizational strategies in s-commerce - especially those related to price, trust, and its antecedents.

Since the results do not provide support to the hypothesis that transaction safety has a significant effect on consumer trust in s-commerce, we perceive some practical initiatives that can be explored in order to become more relevant to this relationship. Perhaps they have not yet been fully implemented on the investigated websites. With the growth of online commerce, certificates and secure seals associated with websites have emerged in order to bring greater security to buyers, since they display the credibility of online stores. In this sense, perhaps to increase trust in scommerce, companies could intensify the use of trust seal images from companies that legitimate the services and products from the website based on customers recommendations or even indicate the presence of SSL/TLS - Secure Sockets Layer (SSL) and Transport Layer Security (TLS), meaning the website connects over the net and data transmitted between the visitor's browser

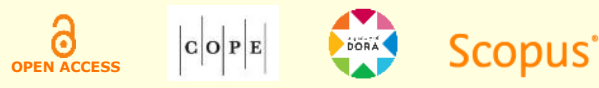


and the server is encrypted. The main benefit of having a secure store is that in addition to the credibility that will pass to the customer, it will help prevent fraud and leakage of confidential customer information. The insertion of secure site seals and the presence of information on wellvisible privacy policies add value to the brand, differentiating it from the others and gaining the trust of users. In addition, companies should beware of ensuring the authenticity of reviews and ratings, which will certainly attract new customers.

Another measure that can increase consumer trust in a particular website is to provide as much information as possible to the user to make the buying process and product as tangible as possible. Comprehensive, diversified, latest, and accurate information makes all the difference at the time of purchase. Providing complete descriptions with all the technical details about the item, suitable tools for customer understanding, good customer service systems, interface and collaboration with customers, and ease of navigation are other aspects related to the quality of information that can contribute to the increase of trust with the website.

In addition, care with the product delivery process also needs the attention of the companies. When compared with physical stores, consumers in online shopping do not immediately possess the purchased product, once they have to wait a certain amount of time in order to receive the product. Thus, comments and reviews from other consumers about aspects of product delivery influence the individual's perception regarding the company's performance in this factor, which will positively or negatively influence his/her trust in the website. In this sense, firms should be concerned with the ability to handle returns, offer online full tracking of orders and deliveries, as well as meeting the expectations of delivery locations. Establishing partnerships with thirdparty logistics providers can be an attractive strategy for s-commerce firms, which can reduce the time and improve the quality of product delivery. All attributes contribute significantly to increasing customer trust in s-commerce and thereby making their selling prices more competitive, both for monetary and other nonmonetary attributes that add value to the product.

In order to minimize the doubts during the first transactions, website reputation can provide reassurance that it is trustworthy and will behave in accordance with the consumer confident expectations. This is why establishing a good reputation after the initial transaction is crucial. Thus, improving the reputation of social commerce will improve trusting beliefs, as it indicates that the website has positive general characteristics, traits that are absent on websites with a poor reputation. In social commerce, this can be facilitated by social technologies such as customer reviews, information, and experiences of others in forums and communities. For instance, when a reputable member of an online forum or community makes a recommendation to a vendor by giving good feedback, the other members are likely to have a high level of trust in the process (Y. Lu, Zhao, \& Wang, 2010). Therefore, the firms may engage with their consumers in social platforms such as forums and communities, recommendations and referrals, and ratings and reviews to develop reputation and trust.

To researchers, we offer an adequate framework of the phenomenon, corroborating the results of previous studies predicting purchase intention. Besides, comparing the proposed model in this study with Kim and Park's model reconfigures the construct economic feasibility to competitive

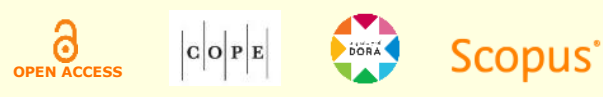


price, altering its items and showing the latter as an antecedent of the purchasing decision of consumers in s-commerce, which was not evaluated by S. Kim and Park (2013). Another contribution of the study is the proposition of the construct product delivery as an important antecedent of trust in s-commerce, once this relationship had not been tested and found before in the literature.

As limitations of the study, we highlight the selection of the study participants, all members of the social network Facebook. Therefore, we should be cautious about the generalization of the results. With regard to future research, we suggest investigations using more appropriate analyses to reveal purchases where the price is decisive in consumer choice or when buying is more influenced by consumer trust in the online seller, increasing their willingness to pay a premium price. In this sense, some moderator variables could be used to improve the model, for example, regarding the frequency of purchase on the Internet, repurchase from the same online store, and the time that the person spends on the site to buy. Furthermore, we suggest investigating other elements that may contribute to the explanatory power of the model; for example, the influence of the recommendation of peers on the firm's reputation cab be investigated. Finally, we suggest conducting further studies that establish relations among these constructs in specific product segments, in order to verify if the relations found in this study are confirmed and are intensified depending on the type of product purchased online.

\section{References}

Ba, S., Stallaert, J., \& Zhang, Z. (2007). Price competition in e-tailing under service and recognition differentiation. Electronic Commerce Research and Applications, 6(3), 322-331. https://doi.org/10.1016/j.elerap.2006.06.005

Busalim, A. H., \& Hussin, A. R. C. (2016). Understanding social commerce: A systematic literature review and directions for further research. International Journal of Information Management, 36(6), 1075-1088. https://doi.org/10.1016/j.ijinfomgt.2016.06.005

Campaign Brief. (2012, July 17). Burson-Marsteller study finds youtube is the fastest growing platform among fortune global 100 in the global social media check-up 2012. Retrieved May $1^{\text {st }}, 2016$ from https://campaignbrief.com/bursonmarsteller-study-finds/

Chang, H., \& Chen, S. (2008). The impact of online store environment cues on purchase intention: Trust and perceived risk as a mediator. Online Information Review, 32(6), 818-841. https://doi.org/10.1108/14684520810923953

Cheung, M., \& Lee, M. (2006). Understanding consumer trust in Internet shopping: A multidisciplinary approach. Journal of the American Society for Information Science and Technology, 57(4), 479-492. https://doi.org/10.1002/asi.20312

Chin, W. W. (1998). Issues and opinion on structural equation modeling. MIS Quarterly, 22(1), vii-xvi. Retrieved from https://www.jstor.org/stable/249674

Cohen, J. (1988). Statistical power analysis for the behavioral sciences. Hillsdale, NJ: Lawrence Erlbaum.

Cristofolini, J. (2017, February 9). Quais são os quatro grandes problemas do e-commerce. E-commercebrasil. Retrieved September 2, 2018 from https://www.ecommercebrasil.com.br/artigos/4-grandes-problemas-do-e-commerce-ecomo-resolve-los

Delone, W., \& Mclean, E. (2004). Measuring e-commerce success: Applying the DeLone \& McLean information systems success model. International Journal of Electronic Commerce, 9(1), 31-47. https://doi.org/10.1080/10864415.2004.11044317

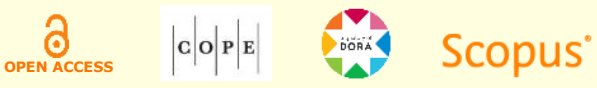


De Valck, K. (2005). Virtual communities of consumption: Networks of consumer knowledge and companionship (Doctoral dissertation). Erasmus Research Institute of Management (ERIM), Erasmus University Rotterdam, Netherlands.

Doney, P., \& Cannon, J. (1997). An examination of the nature of trust in buyer-seller relationships. Journal of Marketing, 61(2), 35-51. https://doi.org/10.1177/002224299706100203

Emarketer. (2016). Ecommerce sites in Brazil embrace social media. Retrieved June 2, 2016 from https://www.emarketer.com/Article/Ecommerce-Sites-Brazil-Embrace-Social-Media/1014032

European Commission. (2013, June). Consumer attitude towards cross-border trade and consumer protection [Flash Eurobarometer 358]. Retrieved from http://ec.europa.eu/public_opinion/flash/fl_358_en.pdf

Flavián, C., Guinalíu, M., \& Gurrea, R. (2006). The role played by perceived usability, satisfaction and consumer trust on website loyalty. Information $\mathbb{E}$ Management, 43(1), 1-14. https://doi.org/10.1016/j.im.2005.01.002.

Fornell, C., \& Larcker, D. F. (1981). Evaluating structural equation models with unobservable variables and measurement error. Journal of Marketing Research, 18(1), 39-50. https://doi.org/10.1177/002224378101800104.

Gefen, D. (2000). E-commerce: The roles of familiarity and trust. Omega, 28(6), 725-737. https://doi.org/10.1016/S0305-0483(00)00021-9

Gefen, D., Karahanna, E., \& Straub, D. W. (2003). Trust and TAM in online shopping: An integrated model. MIS Quarterly, 27(1), 51-90. https://doi.org/10.2307/30036519

Grewal, D., Iyer, G., Krishnan, R., \& Sharman, A. (2003). The Internet and the price value-loyalty chain. Journal of Business Research, 56(5), 391-398. https://doi.org/10.1016/S0148-2963(01)00227-2

Grewal, D., Monroe, K., \& Krishnan, R. (1998). The effects of price-comparison advertising on buyers' perceptions of acquisition value, transaction value, and behavioral intentions. Journal of Marketing, 62(2), 46-59. https://doi.org/10.2307/1252160

Grund, C., \& Gürtler, O. (2008). The effect of reputation on selling prices in auctions. Jahrbücher für Nationalökonomie und Statistik, 228(4), 345-356. https://doi.org/10.1515/jbnst-2008-0404

Hair, J. F., Jr., Hult, G. T. M., Ringle, C., \& Sarstedt, M. (2017). A primer on partial least squares structural equation modeling (PLS-SEM) (2nd ed.). Thousand Oaks, CA: Sage Publications.

Hair, J. F., Risher, J. J., Sarstedt, M., \& Ringle, C. M. (2019). When to use and how to report the results of PLSSEM. European Business Review, 31(1), 2-24. https://doi.org/10.1108/EBR-11-2018-0203

Hair, J. F., Jr., Sarstedt, M., Hopkins, L., \& G. Kuppelwieser, V. (2014). Partial least squares structural equation modeling (PLS-SEM): An emerging tool in business research. European Business Review, 26(2), 106-121. https://doi.org/10.1108/ebr-10-2013-0128

Hajli, M. N. (2014). A study of the impact of social media on consumers. International Journal of Market Research, 56(3), 387-404. https://doi.org/10.2501/IJMR-2014-025

Hajli, M. N. (2015). Social commerce constructs and consumer's intention to buy. International Joumal of Information Management, 35(2), 183-191. https://doi.org/10.1016/j.ijinfomgt.2014.12.005

Hoffman, D., Novak, T., \& Peralta, M. (1999). Building consumer trust online. Communications of the ACM, 42(4), 80-85. https://doi.org/10.1145/299157.299175

Hong, S. Y., \& Yang, S.-U. (2009). Effects of reputation, relational satisfaction, and customer-company identification on positive word-of-mouth intentions. Journal of Public Relations Research, 21(4), 381-403. https://doi.org/10.1080/10627260902966433

Hsiao, K.-L., Lin, J. C.-C., Wang, X.Y., Lu, H.-P., \& Yu, H. (2010). Antecedents and consequences of trust in online product recommendations: An empirical study in social shopping. Online Information Review, 34(6), 935-953. https://doi.org/10.1108/14684521011099414

Huseynov, F., \& Yildirim, S. Ö. (2016). Internet users' attitudes toward business-to-consumer online shopping: A survey. Information Development, 32(3), 452-465. https://doi.org/10.1177/0266666914554812

Jarvenpaa, S. L., Tractinsky, J., \& Vitale, M. (2000). Consumer trust in an Internet store. Information Technology and Management, 1(1-2), 45-71. https://doi.org/10.1023/A:1019104520776

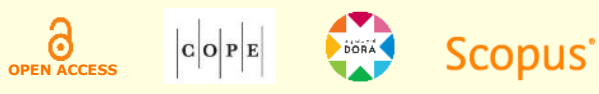


Kemp, S. (2017, August 10). Three billion people now use social media. We Are Social. Retrieved August 9, 2017 from https://wearesocial.com/blog/2017/08/three-billion-people-now-use-social-media

Kim, D. J., Ferrin, D. L., \& Rao, H. R. (2008). A trust-based consumer decision-making model in electronic commerce: The role of trust, perceived risk, and their antecedents. Decision Support Systems, 44(2), 544-564. https://doi.org/10.1016/j.dss.2007.07.001

Kim, H.-W., Xu, Y., \& Gupta, S. (2012). Which is more important in Internet shopping, perceived price or trust? Electronic Commerce Research and Applications, 11(3), 241-252. https://doi.org/10.1016/j.elerap.2011.06.003

Kim, S., \& Park, H. (2013). Effects of various characteristics of social commerce (s-commerce) on consumers' trust and trust performance. International Journal of Information Management, 33(2), 318-332. https://doi.org/10.1016/j.ijinfomgt.2012.11.006

Koufaris, M., \& Hampton-Sosa, W. (2004). The development of initial trust in an online company be new customers. Information $\mathcal{E}$ Management, 41(3), 377-397. https://doi.org/10.1016/j.im.2003.08.004

Koufteros, X. A. (1999). Testing a model of pull production: A paradigm for manufacturing research using structural equation modeling. Journal of Operations Management, 17(4), 467-488. https://doi.org/10.1016/s02726963(99)00002-9

Lee, K., \& Lee, B. (2011). An empirical study on quality uncertainty of products and social commerce. Proceedings of the International Conference on Electronic Commerce, Liverpool, United Kingdom, 13.

Liang, T.-P., \& Turban, E. (2011). Introduction to the special issue social commerce: A research framework for social commerce. International Journal of Electronic Commerce, 16(2), 5-14. https://doi.org/10.2753/JEC10864415160201

Liao, C., Palvia, P., \& Lin, H.-N. (2006). The roles of habit and web site quality in e-commerce. International Journal of Information Management, 26(6), 469-483. https://doi.org/10.1016/j.ijinfomgt.2006.09.001

Lichtenstein, D. R., Ridgway, N. M., \& Netemeyer, R. G. (1993). Price perceptions and consumer shopping behavior: A field study. Journal of Marketing Research, 30(2), 234-245. https://doi.org/10.1177/002224379303000208

Li, C.-Y., \& Ku, Y.-C. (2018). The power of a thumbs-up: Will e-commerce switch to social commerce? Information EB Management, 55(3), 340-357. https://doi.org/10.1016/j.im.2017.09.001

Lin, X., Li, Y., \& Wang, X. (2017). Social commerce research: Definition, research themes and the trends. International Journal of Information Management, 37(3), 190-201. https://doi.org/10.1016/j.ijinfomgt.2016.06.006

Lu, B., Fan, W., \& Zhou, M. (2016). Social presence, trust, and social commerce purchase intention: An empirical research. Computers in Human Behavior, 56(1), 225-237. https://doi.org/10.1016/j.chb.2015.11.057

Lu, Y., Zhao, L., \& Wang, B. (2010). From virtual community members to C2C e-commerce buyers: Trust in virtual communities and its effect on consumers' purchase intention. Electronic Commerce Research $\mathcal{E}$ Applications, 9(4), 346-360. https://doi.org/10.1016/j.elerap.2009.07.003

Luo, X., Li, H., Zhang, J., \& Shim, J. P. (2010). Examining multi-dimensional trust and multifaceted risk in initial acceptance of emerging technologies: An empirical study of mobile banking services. Decision Support Systems, 49(2), 222-234. https://doi.org/10.1016/j.dss.2010.02.008

Maia, C., Lunardi, G., Longaray, A., \& Munhoz, P. (2018). Factors and characteristics that influence consumers' participation in social commerce. Revista de Gestão, 25(2), 1-18. https://doi.org/10.1108/REGE-03-2018-031

Manvi, S. S., \& Venkataram, P. (2005). An intelligent product-information presentation in E-commerce. Electronic Commerce Research and Applications, 4(3), 220-239. https://doi.org/10.1016/j.elerap.2005.01.001

Morgan, R. M., \& Hunt, S. D. (1994). The commitment-trust theory of relationship marketing. Journal of Marketing, 58(3), 20-38. https://doi.org/10.1177/002224299405800302

Oh, J., Yoon, Y., \& Lee, K. (2006). An empirical study on the determinants of trust and purchasing intention in online shopping. Korea Industrial Economics Association, 19(1), 205-224.

Pavlou, P., Liang, H., \& Xue, Y. (2007). Understanding and mitigating uncertainty in online exchange relationships: A principal-agent perspective. MIS Quarterly, 31(1), 105-136. https://doi.org/10.2307/25148783

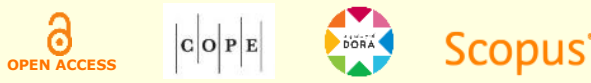


Podsakoff, P., MacKenzie, S., Lee, J., \& Podsakoff, N. (2003). Common method biases in behavioral research: A critical review of the literature and recommended remedies. Journal of Applied Psychology, 88(5), 879-903. https://doi.org/10.1037/0021-9010.88.5.879

PricewaterhouseCoopers. (2013, January). Demystifying the online shopper - 10 myths of multi-channel retailing. Retrieved September 26, 2014 from https://www.pwc.com/gx/en/retail-consumer/retail-consumer-publications/globalmulti-channel-consumer-survey/assets/10_myths_multichannel.pdf

Ramanathan, R. (2010). The moderating roles of risk and efficiency on the relationship between logistics performance and customer loyalty in e-commerce. Transportation Research Part E: Logistics and Transportation Review, 46(6), 950-962. https://doi.org/10.1016/j.tre.2010.02.002

Sullivan, Y. W., \& Kim, D. J. (2018). Assessing the effects of consumers' product evaluations and trust on repurchase intention in e-commerce environments. International Journal of Information Management, 39(1), 199-219. https://doi.org/10.1016/j.ijinfomgt.2017.12.008

Tubenchlak, D., de Faveri, D., Zanini, M., \& Goldszmidt, R. (2015). Motivações da comunicação boca a boca eletrônica positiva entre consumidores no facebook. Revista de Administração Contemporânea, 19(1), 107-126. http://dx.doi.org/10.1590/1982-7849rac20151998

Wang, X., Tajvidi, M., Lin, X., \& Hajli, N. (2019). Towards an ethical and trustworthy social commerce community for brand value co-creation: A trust-commitment perspective. Journal of Business Ethics, 1-16. https://doi.org/10.1007/s10551-019-04182-z

Wetzels, M., Odekerken-Schröder, G., \& Van Oppen, C. (2009). Using PLS path modeling for assessing hierarchical construct models: Guidelines and empirical illustration. MIS Quarterly, 33(1), 177-195. https://doi.org/10.2307/20650284

Yu, J., Subramanian, N., Ning, K., \& Edwards, D. (2015). Product delivery service provider selection and customer satisfaction in the era of Internet of things: A Chinese e-retailers' perspective. International Journal of Production Economics, 159(1), 104-116. https://doi.org/10.1016/j.ijpe.2014.09.031

Zeithaml, V. A. (1988). Consumer perceptions of price, quality, and value: A means-end model and synthesis of evidence. Journal of Marketing, 52(3), 2-22. https://doi.org/10.1177/002224298805200302

Zhang, K. Z. K., \& Benyoucef, M. (2016). Consumer behavior in social commerce: A literature review. Decision Support Systems, 86, 95-108. https://doi.org/10.1016/j.dss.2016.04.001

\section{Author contributions}

$1^{\text {st }}$ author: conceptualization (lead), data curation (lead), formal analysis (equal), investigation (equal), methodology (equal), writing-original draft (equal).

$2^{\text {nd }}$ author: conceptualization (equal), formal analysis (equal), methodology (equal), validation (lead), writing-original draft (equal).

$3^{\text {rd }}$ author: conceptualization (equal), formal analysis (equal), methodology (supporting), validation (equal), writingoriginal draft (equal).

$4^{\text {th }}$ author: conceptualization (supporting), formal analysis (equal), methodology (equal), validation (supporting), writing-original draft (equal). 


\section{Authors}

\section{Cláudia Rodrigues Maia}

Universidade Federal do Rio Grande do Sul, Programa de Pós-Graduação em Administração

Rua Washington Luiz, 855, 90010-460, Porto Alegre, RS, Brazil

claudiarmaia@hotmail.com

(iD) https://orcid.org/0000-0002-7274-0118

\section{Guilherme Lerch Lunardi}

Universidade Federal do Rio Grande do Sul, Programa de Pós-Graduação em Administração

Rua Washington Luiz, 855, 90010-460, Porto Alegre, RS, Brazil

gllunardi@furg.br

(iD) https://orcid.org/0000-0003-3250-2796

\section{Décio Dolci}

Universidade Federal do Rio Grande, Instituto de Ciências Econômicas, Administrativas e Contábeis Av. Italia Km 8, 96201-900, Rio Grande, RS, Brazil

dbdolci@gmail.com

(iD) https://orcid.org/0000-0002-6141-3357

\section{Lívia Castro D'Avila}

Universidade Federal do Rio Grande, Instituto de Ciências Econômicas, Administrativas e Contábeis Av. Italia Km 8, 96201-900, Rio Grande, RS, Brazil

liviacdavila@gmail.com

(iD) https://orcid.org/0000-0002-8622-5416 


\section{APPENDIX}

Measurement items

\begin{tabular}{|c|c|c|c|c|}
\hline Constructs & $\mathbf{n}$ & Mean & SD & VIF \\
\hline Reputation - S. Kim and Park (2013) & 160 & 4.48 & .64 & 1.47 \\
\hline REPUT1. This s-commerce firm is well known & 160 & 4.43 & .87 & 1.84 \\
\hline REPUT2. This s-commerce firm has a good reputation & 160 & 4.48 & .66 & 1.29 \\
\hline REPUT3. This s-commerce firm has the reputation for being honest* & 160 & 4.43 & .67 & \\
\hline REPUT4. I am familiar with the name of this s-commerce firm & 157 & 4.53 & .80 & 1.95 \\
\hline Information Quality - S. Kim and Park (2013) & 160 & 4.34 & .61 & 1.86 \\
\hline $\begin{array}{l}\text { INFO1. This s-commerce firm provides accurate information about the item that you want } \\
\text { to purchase }\end{array}$ & 157 & 4.44 & .69 & 1.39 \\
\hline INFO2. Overall, I think this s-commerce firm provides useful information & 158 & 4.22 & .82 & 1.49 \\
\hline $\begin{array}{l}\text { INFO3. This s-commerce firm site provides sufficient information when I try to make a } \\
\text { transaction }\end{array}$ & 159 & 4.33 & .73 & 1.45 \\
\hline INFO4. This s-commerce firm provides reliable information* & 158 & 4.33 & .79 & \\
\hline Trust - S. Kim and Park (2013) & 160 & 4.35 & .64 & 1.31 \\
\hline TRUST1. This s-commerce firm is trustworthy & 160 & 4.51 & .63 & 1.47 \\
\hline $\begin{array}{l}\text { TRUST2. This s-commerce firm, despite having its own interests, takes into consideration } \\
\text { what is best for me too* }\end{array}$ & 160 & 3.58 & .94 & \\
\hline TRUST3. I believe in this s-commerce firm & 158 & 4.28 & .84 & 2.06 \\
\hline $\begin{array}{l}\text { TRUST4. This s-commerce firm wants to be known as a company that keeps its promises } \\
\text { and commitments }\end{array}$ & 159 & 4.25 & .78 & 1.94 \\
\hline Competitive Price - adapted by S. Kim and Park (2013) & 160 & 4.23 & .64 & 1.31 \\
\hline PRICE1. This s-commerce firm provides attractive and valuable products & 160 & 4.38 & .81 & 1.19 \\
\hline PRICE2. This s-commerce firm offers reasonable and satisfactory prices & 160 & 4.18 & .82 & 1.64 \\
\hline PRICE3. I can buy products or services at low prices through this s-commerce firm & 160 & 4.13 & .91 & 1.43 \\
\hline Product Delivery - Maia et al. (2018) & 160 & 4.08 & .81 & 1.37 \\
\hline DEL1. The delivery time defined by the site is attractive & 158 & 4.05 & 1.00 & 1.79 \\
\hline DEL2. The shipping (when) charged by the delivery of the product is fair & 159 & 3.95 & 1.11 & 1.32 \\
\hline DEL3. The means of delivery of the product are satisfying & 159 & 4.24 & .85 & 1.98 \\
\hline Transaction Safety - S. Kim and Park (2013) & 160 & 4.17 & .74 & 1.97 \\
\hline SAFE1. This s-commerce site implements security measures to protect its online shoppers & 158 & 4.29 & .91 & 1.50 \\
\hline $\begin{array}{l}\text { SAFE2. This s-commerce site has the ability to verify the identity of online shoppers for } \\
\text { security purposes* }\end{array}$ & 158 & 3.80 & .93 & \\
\hline $\begin{array}{l}\text { SAFE3. This s-commerce site usually ensures transaction-related information is protected } \\
\text { from being accidentally altered or destroyed during transmission over the Internet }\end{array}$ & 160 & 3.88 & 1.01 & 1.33 \\
\hline SAFE4. I feel secure about the electronic payment system of this s-commerce website & 160 & 4.34 & .84 & 1.47 \\
\hline Purchase Intention - S. Kim and Park (2013) & 160 & 4.36 & .80 & - \\
\hline BUY1. I am likely to purchase products/services in this s-commerce site & 159 & 4.50 & .82 & 3.26 \\
\hline BUY2. It is likely that I will purchase products on this s-commerce site in the near future & 159 & 4.14 & 1.01 & 2.35 \\
\hline BUY3. Given the opportunity, I intend to purchase products on this s-commerce site & 158 & 4.45 & .80 & 4.00 \\
\hline
\end{tabular}

Note. ${ }^{*}$ Items were deleted during pretest analysis. 